\title{
Pengaruh Faktor Riwayat Lahir dan Sosial Ekonomi terhadap Gizi Lebih pada Remaja
}

\author{
Birth History and Socio-Economic Factor related to Over Nutrition in \\ Adolescent \\ Elita Oktorina Pasaribu', Drajat Martianto², Cesilia Meti Dwiriani² \\ 1,2Departemen Gizi Masyarakat, Fakultas Ekologi Manusia, Institut Pertanian Bogor
}

\begin{abstract}
ABSTRAK
Obesitas merupakan masalah utama di dunia terutama pada remaja yang prevalensinya terus meningkat dan penyebab obesitas pada remaja bersifat multifaktor. Riwayat lahir dan sosial ekonomi menjadi faktor yang berpengaruh terhadap obesitas. Tujuan penelitian ini adalah mengidentifikasi faktor riwayat lahir dan sosial ekonomi terhadap gizi lebih pada remaja. Desain penelitian ini adalah kohort menggunakan data sekunder dari Indonesian Family Life Surveys (IFLS) dan dilaksanakan pada Desember 2017 - Agustus 2018. Sampel dalam penelitian ini adalah remaja usia 15-17 tahun berjumlah 426 responden. Analisis statistik yang digunakan adalah Structural Equation Modeling (SEM). Pengaruh langsung terhadap berat lahir ditemukan bahwa hanya usia kehamilan berpengaruh signifikan $(\mathrm{OR}=7,7)(\mathrm{p}<0,05)$. Pengaruh langsung terhadap gizi lebih remaja ditemukan pendidikan ayah $(p<0,05)$ dan IMT ibu $(p<0,05)$ berpengaruh signifikan, sedangkan pendidikan ibu $(p>0,05)$, pendapatan/kapita/ bulan $(p>0,05)$, dan wilayah tinggal $(p>0,05)$ tidak ditemukan hasil yang signifikan terhadap gizi lebih pada remaja. Remaja yang memiliki ayah berpendidikan semakin tinggi dan ibu yang gemuk atau obesitas menjadi faktor risiko remaja menjadi gizi lebih.
\end{abstract}

Kata kunci : Gemuk, obesitas, riwayat lahir, sosio ekonomi

\begin{abstract}
Obesity is a major problem in the world, especially in adolescents whose prevalence increase and obesity in adolescents are multi-factorial desease. Birth history and socio-economic factors that influence obesity. The purpose of this study was to identify birth history and socio-economic factors for over nutrition in adolescents. The design of this study is a cohort study using secondary data from the Indonesian Family Life Surveys (IFLS) and carried out from December 2017 - August 2018. The study involved 426 adolescents aged 15-17 years. The statistical analysis used is Structural Equation Modeling (SEM). The direct effect on birth weight was gestational age (OR 7.7) $(p<0.05)$. The direct effect of adolescent nutritional status was found in father's education $(p<0.05)$ and maternal BMI $(p<0.05)$ had a significant effect, while maternal education $(p>0.05)$, income / capita / month $(p>0.05)$, and the living area $(p>0.05)$ did not find significant results for over nutrition in adolescents. Adolescents who have highly educated fathers and overweight or obese mothers are risk factor for adolescents to become over nutrition.
\end{abstract}

Keywords : Overweight, obesity, prenatal history, socio-economic 


\section{PENDAHULUAN}

Obesitas anak saat ini merupakan masalah paling serius pada abad ini. Secara global sekitar 1 dari 10 anak usia 5 - 17 tahun mengalami gemuk atau obesitas dimana peningkatan prevalensinya secara cepat berkembang di banyak negara dan wilayah dalam beberapa tahun terakhir. Sebagian besar anak gemuk dan obesitas saat ini banyak ditemukan pada negara berkembang, laju peningkatan prevalensinya lebih tinggi dibanding negara maju. ${ }^{1}$

Berdasarkan data Riskesdas remaja usia 13-15 tahun memiliki prevalensi gemuk 8,3\% dan obesitas $2,5 \%$. Pada remaja usia 16-18 tahun prevalensi gemuk sebanyak $5,7 \%$ dan obesitas sebanyak $1,6 \%{ }^{2}$ Gemuk dan obesitas sering dikaitkan dengan terjadinya peningkatan diabetes melitus tipe 1, hipertensi, penyakit kardiovaskular dan kanker. Obesitas merupakan kondisi dengan etiologi multifaktor dengan determinan yang memengaruhi terkait genetik dan lingkungan. ${ }^{3}$

Seribu hari pertama kehidupan (1000 HPK) merupakan suatu periode didalam proses pertumbuhan dan perkembangan yang di mulai sejak konsepsi sampai anak berusia 2 tahun. Asupan makanan selama 1000 HPK memberi konsekuensi kesehatan untuk masa depan agar anak tumbuh sehat dan cerdas maka gizi sejak anak dini harus terpenuhi dengan tepat dan optimal. Periode ini mencakup 270 hari masa kehamilan, 180 hari masa pemberian ASI eksklusif, dan 550 hari masa pemberian ASI dan makanan pendamping ASI. ${ }^{4}$ Dasar kesehatan seseorang terbentuk mulai dari masa awal kehidupan bahkan sejak dalam masa kehamilan. Pentingnya pertumbuhan prenatal pada kesehatan jangka panjang telah diteliti sebelumnya. Berdasarkan teori tersebut disebutkan bahwa kehidupan awal sejak masih dalam kandungan dapat berdampak jangka panjang terhadap kesehatan. ${ }^{5}$ Hari pertama kelahiran sangat penting, banyak perubahan yang terjadi pada bayi dalam menyesuaikan diri dari kehidupan di dalam rahim sampai masa kehidupan setelah lahir. ${ }^{6}$ Masa awal kehidupan seperti lahir prematur dan berat lahir menjadi faktor yang memengaruhi obesitas namun hasil yang temukan pada penelitian sebelumnya masih belum konsisten. ${ }^{3}$

Durasi menyusui ditemukan berhubungan negatif dengan risiko obesitas pada masa anak- anak. ${ }^{7}$ Selain itu sebuah analisis literatur pada 9 penelitian telah menyimpulkan bahwa menyusui tampaknya memiliki efek protektif yang kecil namun konsisten terhadap obesitas pada anak-anak. ${ }^{8}$ Selain ASI, berat lahir telah digunakan sebagai indikator dasar untuk menetapkan konsep dasar yang sangat berpengaruh terhadap kejadian obesitas pada anak. ${ }^{9}$ Komitmen pemerintah dalam upaya percepatan perbaikan gizi telah dinyatakan melalui Perpres Nomor 42 Tahun 2013, tentang Gerakan Nasional (Gernas) Percepatan Perbaikan Gizi yang merupakan upaya bersama antara pemerintah dan masyarakat melalui penggalangan partisipasi dan kepedulian pemangku kepentingan secara terencana dan terkoordinasi untuk percepatan perbaikan gizi masyarakat dengan prioritas pada Seribu Hari Pertama Kehidupan (1000 HPK). ${ }^{10}$ Upaya perbaikan gizi tersebut sering dikaitkan dengan pencegahan stunting, namun belum banyak ditemukan penelitian yang mengkaji terkait 1000 HPK terhadap obesitas pada masa remaja.

Selain terkait dengan faktor prenatal dan pasca natal, obesitas juga dipengaruhi faktor lain seperti gender, status gizi orang tua, pendidikan orang tua. ${ }^{11}$ Kerangka UNICEF 1990 menunjukkan bahwa kemampuan rumah tangga dalam mengakses kuantitas dan kualitas sumber daya pangan, pendidikan, pekerjaan dan pendapatan menjadi dasar penyebab terjadinya perubahan status gizi pada anak dan juga ibu hamil. ${ }^{12}$ Pada level rumah tangga, pendapatan dan kekayaan berhubungan dengan pertumbuhan anak. Pendapatan tersebut akan memengaruhi daya beli dan pola asuh yang tepat yang berkaitan dengan kesehatan anak. Pendapatan yang semakin tinggi dapat meningkatkan kemampuan untuk memenuhi kuantitas makanan bergizi, air bersih, pakaian, ventilasi rumah yang cukup, bahan makanan untuk memasak, tempat penyimpanan makanan, higienitas personal, dan layanan kesehatan. ${ }^{13}$ Oleh karena itu, tujuan dari penelitian ini adalah untuk menganalisis faktor riwayat lahir dan sosial ekonomi terhadap obesitas pada remaja.

\section{BAHAN DAN METODE}

Penelitian ini menggunakan desain cohort. Data yang dianalisis merupakan data sekunder dari Indonesian Family Life Survey (IFLS). ${ }^{14-16}$ 
Dari lima gelombang data, penelitian ini menggunakan data dari gelombang tiga (tahun 2000) dan lima (tahun 2014) dimana sampel yang diambil adalah anak usia 15-17 tahun pada tahun 2014. Penelitian ini dilakukan Desember 2017 - Agustus 2018. Kriteria inklusi pada penelitian ini adalah: 1) Bayi yang memiliki data berat lahir pada tahun 2000; 2) Memiliki data status gizi 2014; 3) Bayi lahir tunggal; 4) Memiliki data pemberian ASI saja dan sosial ekonomi (pendidikan dan pendapatan ayah dan ibu); 5) Memiliki data karakteristik ibu pada saat masa kehamilan; 6) Memiliki data IMT ibu pada saat anak remaja. Kriteria eksklusi yang digunakan adalah: 1) Status gizi kurus; 2) Data yang merupakan pencilan. Dalam penelitian ini, semua yang sesuai dengan kriteria inklusi eksklusi akan dijadikan sampel dan dianalisis. Jumlah sampel pada tahun 2000 adalah 3118 anak. Data anak yang lengkap dari tahun 2000 - 2014 berjumlah 531 anak. Setelah dikurangi dengan data yang outlier jumlah responden menjadi 461. Ketika dianalisis masih terdapat perubahan status gizi anak yang menjadi kurus pada tahun 2014 sehingga di keluarkan dalam penelitian, sehingga total responden adalah 426 anak.
Data yang digunakan dalam penelitian ini meliputi data anak (usia, berat lahir, durasi pemberian ASI saja, total ANC, jenis kelamin dan status gizi) dan data orang tua (pendapatan, pendidikan, usia kehamilan, usia ibu saat hamil, ) serta data wilayah tempat tinggal. Data yang diperoleh dari IFLS terkait dengan pengumpulan data pendidikan, pendapatan, tempat tinggal diperoleh melalui kuesioner, sedangkan data mengenai status gizi diperoleh dengan melakukan pengukuran antropometri. Pengumpulan data antropometri menggunakan standar pengukuran berat dan tinggi badan internasional. Alat yang digunakan untuk mengukur berat badan adalah timbangan digital Seca Model 770, sedangkan alat yang digunakan untuk mengukur tinggi dan panjang badan adalah Shorr measuring boards. Seca Model 770 memiliki keakuratan sampai mendekati $0,1 \mathrm{~kg}$. Status gizi (IMT/U) diolah menggunakan WHO Anthro Plus. Kategori status gizi berdasarkan Kemenkes $(2012)^{17}$ status gizi normal ( $Z$ skor $>-2$ SD $<+1$ $\mathrm{SD})$, dan status gizi obes ( $\mathrm{Z}>+2 \mathrm{SD})$. Uji yang digunakan untuk mengetahui determinan pada obesitas dengan menggunakan Structural Equation Modeling (SEM). Analisis data dan pengolahan-

Tabel 1. Karakteristik Riwayat Lahir Responden dan Ibu Responden

\begin{tabular}{|c|c|c|}
\hline Variabel & $\mathbf{n}$ & $\%$ \\
\hline \multicolumn{3}{|l|}{ Usia Kehamilan } \\
\hline Bayi lahir kurang bulan (<37 minggu) & 31 & 8,7 \\
\hline Bayi lahir cukup bulan (37-42 minggu) & 382 & 89,7 \\
\hline Bayi lahir lebih bulan ( $>42$ minggu) & 7 & 1,6 \\
\hline \multicolumn{3}{|l|}{ Berat Bayi Lahir } \\
\hline Rendah $(<2,500$ gram $)$ & 23 & 5,4 \\
\hline Cukup/Normal (2,500-4,000 gram) & 383 & 89,9 \\
\hline Tinggi (>4,000 gram) & 20 & 4,7 \\
\hline \multicolumn{3}{|l|}{ Durasi ASI Eksklusif } \\
\hline Kurang $(<6$ bulan) & 400 & 93,9 \\
\hline Cukup ( $>6$ bulan) & 26 & 6,1 \\
\hline \multicolumn{3}{|l|}{ Usia Hamil } \\
\hline Terlalu Muda ( $<20$ tahun) & 44 & 10,3 \\
\hline Usia Cukup (20-37 tahun) & 332 & 77,9 \\
\hline Terlalu Tua ( $>37$ tahun) & 50 & 11,7 \\
\hline \multicolumn{3}{|l|}{ Kunjungan Antenatal Care } \\
\hline Lengkap $(\min 4 \mathrm{x})$ & 126 & 29,6 \\
\hline Tidak lengkap & 300 & 70,4 \\
\hline \multicolumn{3}{|l|}{ Status Gizi Ibu 2014} \\
\hline Kurus & 15 & 3,5 \\
\hline Normal & 138 & 32,4 \\
\hline Gemuk & 96 & 22,5 \\
\hline Obesitas & 177 & 41,5 \\
\hline
\end{tabular}


nya menggunakan perangkat program komputer Microsoft excel 2010, Stata dan Software Statistical Program for Social Science (SPPS) versi 23.

\section{HASIL}

Berdasarkan sebaran data dalam penelitian ini, sebagian besar $(51,4 \%)$ anak berusia 15 tahun dan tersebar cukup merata antara laki-laki dan perempuan. Berdasarkan tingkat pendidikan baik ayah maupun ibu serta pendapatan/kapita/bulan sebagian besar masuk dalam kategori sedang, dan sebanyak $64,1 \%$ tinggal di kota. Karakteristik riwayat lahir sampel dan ibu sampel dalam penelitian ini terdiri dari usia kehamilan, berat bayi lahir, durasi konsumsi ASI eksklusif, usia ibu saat hamil, kunjungan Antenatal Care (ANC), dan status gizi ibu pada tahun 2014. Karakteristik riwayat lahir responden dan ibu dapat dilihat pada Tabel 1.

Berdasarkan usia kehamilan, sebagian besar $(89,7 \%)$ anak lahir dengan usia cukup bulan $(<37$ minggu) dan sebanyak $89,9 \%$ anak lahir dengan berat bayi lahir normal (2,500-4,000 gram). Pemberian ASI merupakan hal yang tidak dapat dipisahkan dari anak-anak karena komponen zat gizi yang sangat penting pada ASI, oleh karena pentingnya zat gizi yang ada pada ASI diantaranya makronutrien, mikronutrien dan komponen lain seperti immunoglobulin, lactoferrin, lisozime, growth factor, karnitin, maka penting untuk memberikan
ASI sampai usia 2 tahun. ${ }^{18}$ Hasil penelitian ini menunjukkan hampir seluruh $(93,9 \%)$ anak tidak mendapat ASI yang cukup selama 6 bulan pertama.

Jika dilihat berdasarkan riwayat ibu, dapat diketahui bahwa sebanyak 22\% ibu hamil pada usia berisiko yaitu terlalu tua ( $>37$ tahun) atau terlalu muda $(<20$ tahun) untuk hamil dimana $10,3 \%$ diantaranya adalah ibu yang hamil pada usia terlalu muda dan $11,7 \%$ ibu hamil pada usia yang terlalu tua. Pada saat hamil sebagian besar $(70,4 \%)$ ibu tidak memeriksakan kehamilan atau tidak melakukan ANC (Antenatal Care) secara lengkap yaitu setidaknya 4 kali selama masa kehamilan. Satu kali pada masa trimester pertama, satu kali pemeriksaan pada trimester kedua dan dua kali pemerikasaaan kehamilan pada trimester ketiga. Usia saat hamil dan pemeriksaan kehamilan sangat penting untuk kesehatan janin. Oleh karena banyaknya yang hamil pada usia berisiko dan tidak memeriksakan kehamilan secara rutin tentu sangat berisiko terhadap pertumbuhan dan perkembangan janin maupun pertumbuhan setelah lahir. Beberapa studi menyebutkan hasil bahwa usia saat hamil terlalu muda dan terlalu tua dapat menyebabkan risiko bayi lahir dengan berat bayi rendah atau tinggi, selain itu juga dapat berisiko terhadap ibu yaitu antara lain dapat menyebabkan keguguran, pre-eklamsia. Pada usia ibu yang

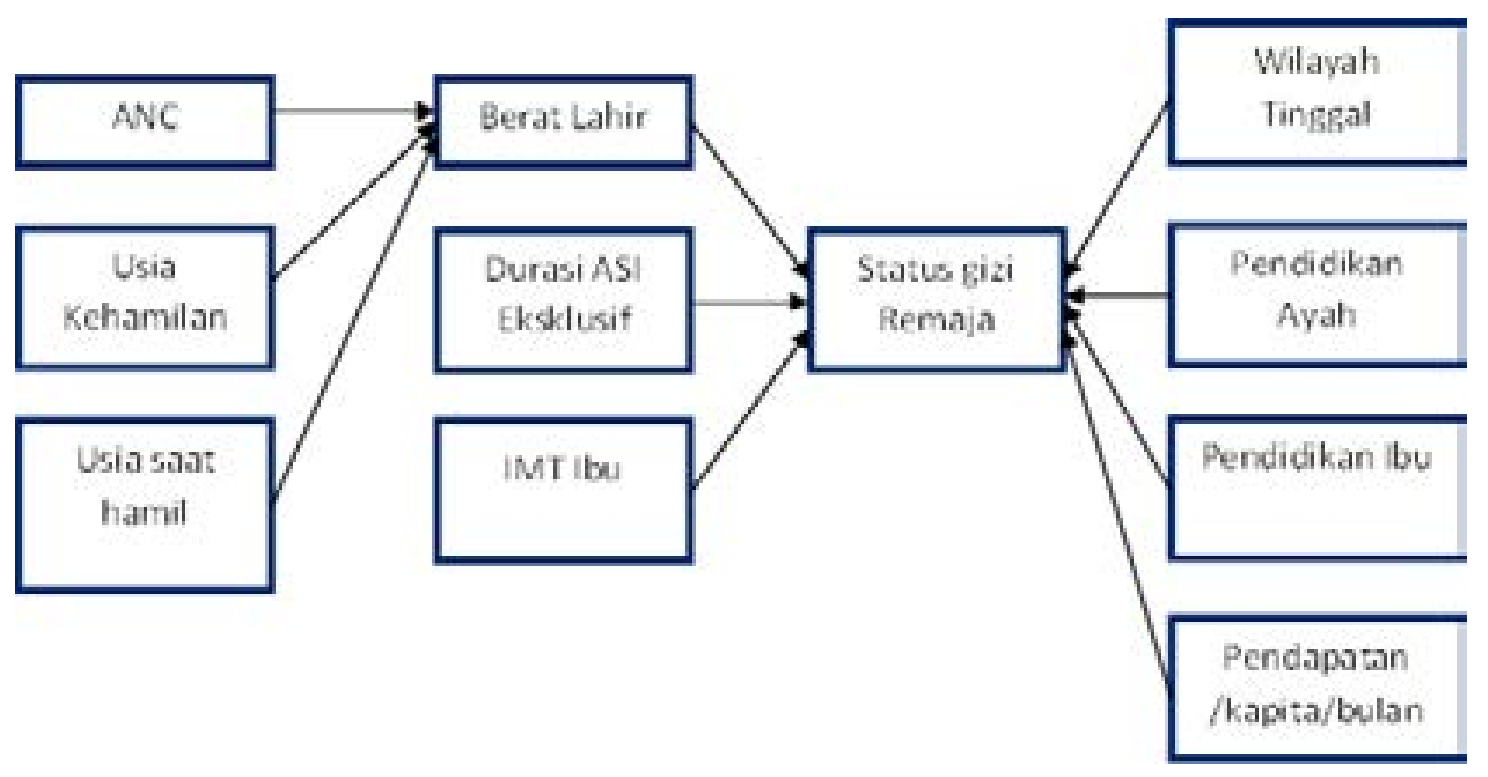

Gambar 1. Analisis SEM Faktor Riwayat Lahir dan Sosio ekonomi terhadap Gizi Lebih pada Remaja 
Tabel 2. Pengaruh Faktor Riwayat Lahir dan Sosio ekonomi terhadap Gizi Lebih pada Remaja

\begin{tabular}{|c|c|c|c|c|c|}
\hline \multirow{2}{*}{ Variabel Dependen } & \multirow{2}{*}{ Variabel Independen } & \multirow{2}{*}{ p-value } & \multirow{2}{*}{ OR } & \multicolumn{2}{|c|}{$95 \% \mathrm{CI}$} \\
\hline & & & & $\mathbf{L L}$ & $\mathbf{U L}$ \\
\hline \multicolumn{6}{|l|}{ Pengaruh Langsung } \\
\hline \multirow[t]{3}{*}{ Berat Bayi Lahir } & Total ANC & 0,785 & 1,1 & 0,54 & 2,23 \\
\hline & Usia Kehamilan & $0,000^{*}$ & 7,99 & 3,53 & 18,07 \\
\hline & Usia Ibu Saat Hamil & 0,965 & 0,7 & 0,35 & 1,41 \\
\hline \multirow[t]{7}{*}{ Status gizi Remaja } & Berat Bayi lahir & 0,972 & 0,99 & 0,73 & 1,34 \\
\hline & Durasi ASI Eksklusif & 0,266 & 1,25 & 0,82 & 1,88 \\
\hline & $\mathrm{IMT} \mathrm{Ibu}^{\mathrm{a}}$ & $0,000^{*}$ & 1,26 & 0,13 & 1,4 \\
\hline & Pendidikan Ayah ${ }^{\mathrm{a}}$ & $0,001^{*}$ & 1,34 & 1,12 & 1,61 \\
\hline & Pendidikan Ibu ${ }^{\mathrm{a}}$ & 0,688 & 0,96 & 0,79 & 1,15 \\
\hline & Pendapatan per Kapita & 0,083 & 0,91 & 0,83 & 1,01 \\
\hline & Wilayah Tinggal ${ }^{a}$ & 0,08 & 0,82 & 0,67 & 1,02 \\
\hline Log Likelihood & -770.13998 & & & & \\
\hline
\end{tabular}

*Signifikansi p-value $<0,05$ uji Structural Equation Model

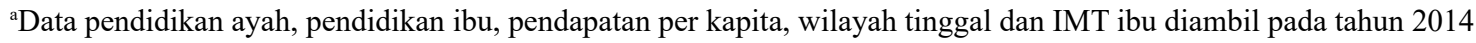

terlalu muda cenderung berisiko pada anak yang mengalami gizi kurang hal ini berkaitan dengan kurangnya pengetahuan tentang menyusui yang berdampak pada pemberian ASI yang terlalu singkat. ${ }^{19}$

Status gizi ibu dihitung berdasarkan berat badan ibu yang diukur pada tahun 2014. Karakteristik status gizi ibu responden sebanyak $41,5 \%$ mengalami obesitas dan $22,5 \%$ mengalami kegemukan. Hasil tersebut menunjukkan bahwa hampir dua per tiga (64\%) ibu mengalami gizi lebih dan ini tentunya menjadi sorotan yang penting mengingat pentingnya peranan ibu terhadap status gizi anak dalam rumah tangga.

Hasil penelitian ini menemukan prevalensi gizi lebih pada remaja tahun 2014 adalah 13,9\% dengan prevalensi gemuk lebih tinggi dibanding prevalensi obesitas. Prevalensi gemuk pada remaja umur 16 - 18 tahun sebanyak 7,3\% yang terdiri dari $5,7 \%$ gemuk dan $1,6 \%$ obesitas. $^{2}$ Kesehatan dan status gizi ibu selama dan sebelum hamil diduga sangat berpengaruh terhadap kehamilan. Status gizi yang rendah dan asupan makan yang tidak mencukupi selama hamil tidak hanya berdampak pada kesehatan ibu namun juga berdampak pada berat lahir dan perkembangan janin. ${ }^{20}$ Maka dari itu, dalam penelitian ini dikaji pengaruh riwayat lahir sebagi faktor yang mempengaruhi gizi lebih pada anak. Gambar 1 menjelaskan faktor-faktor yang mempengaruhi gizi lebih pada remaja baik secara langsung maupun tidak langsung.
Obesitas merupakan kondisi yang sangatlah kompleks, dimana faktor yang memengaruhi dapat terjadi dari berbagai kondisi/multifaktorial seperti faktor genetik dan faktor non-genetik. ${ }^{21}$ Hasil analisis determinan faktor genetik dan non genetik terhadap gizi lebih dapat dilihat pada Tabel 2. Hasil analisis menunjukkan faktor yang berpengaruh secara langsung terhadap berat lahir adalah usia kehamilan ibu $(\mathrm{p}<0,05)$. Ibu yang hamil pada kategori usia tua untuk hamil, berpeluang untuk melahirkan bayi dengan berat lahir yang semakin tinggi, yaitu sebesar 7,7 kali lebih tinggi. Jika dilihat berdasarkan total pemeriksaan kehamilan atau ANC $(p>0,05)$ dan usia ibu saat hamil $(p>0,05)$ tidak ditemukan pengaruh terhadap berat bayi lahir. Pemberian ASI khususnya durasi yang panjang ( $>6$ bulan) dan pengenalan susu formula yang tidak terlalu cepat sangat direkomendasikan untuk mencegah peningkatan lemak pada anak-anak, remaja, dan dewasa awal. ${ }^{22}$ Namun, dalam penelitian ini, durasi pemberian ASI saja kurang dari 6 bulan tidak berpengaruh signifikan terhadap gizi lebih pada remaja $(\mathrm{p}>0,05)$.

Status gizi ibu atau IMT ibu merupakan faktor genetik yang dapat memengaruhi status gizi anak. Penelitian ini menemukan pengaruh yang signifikan antara IMT ibu yang dengan status gizi remaja. Anak dengan ibu yang memiliki status gizi lebih (gemuk atau obesitas) berisiko 1,26 kali lebih tinggi untuk mengalami gizi lebih pada remaja. Selain status gizi ibu, pendidikan ayah juga 
berpengaruh terhadap gizi lebih pada remaja. Ayah dengan pendidikan semakin tinggi justru menjadi salah satu faktor risiko gizi lebih pada remaja dengan nilai $\mathrm{OR}=1,34(\mathrm{p}<0,05)$. Berbeda dengan pendidikan ayah, hasil studi ini menunjukkan bahwa pendidikan ibu tidak berpengaruh terhadap gizi lebih remaja $(p>0,05)$. Demikian pula dengan pendapatan/kapita/bulan, penelitian ini tidak menemukan hasil yang signifikan terhadap gizi lebih remaja ( $p>0,05$ ). Wilayah tempat tinggal juga tidak berhubungan signifkan dengan gizi lebih pada remaja dalam penelitian ini $(\mathrm{p}>0,05)$.

\section{PEMBAHASAN}

Berat lahir rendah (BBLR) adalah indikator yang andal dan sensitif untuk memprediksi hasil jangka pendek dan jangka panjang bayi baru lahir. Berat lahir adalah proksi pertumbuhan intrauterin dan tampaknya terkait dengan komposisi tubuh. Penelitian menyebutkan dimana usia kehamilan, usia ibu, antenatal care (ANC), tinggi badan ibu, berat badan ibu, anemia, aktivitas fisik, merokok, merupakan determinan berat lahir rendah. ${ }^{23}$ Dalam penelitian ini variabel yang diteliti terkait dengan berat lahir adalah usia kehamilan ibu, antenatal care, dan usia ibu saat hamil.

Usia kehamilan ibu berpengaruh signifikan terhadap berat lahir. Dalam penelitian ini menemukan bahwa usia kehamilan ibu yang semakin tua, maka berpeluang untuk melahirkan bayi dengan berat lahir 7,7 kali lebih tinggi. Hal ini sesuai dengan penelitian sebelumnya bahwa usia kehamilan dapat menentukan berat lahir janin, semakin tua usia kehamilan maka berat badan janin akan semakin bertambah. Pada umur kehamilan 28 minggu berat janin kurang lebih 1000 gram, sedangkan pada kehamilan 37 - 42 minggu berat janin diperkirakan mencapai 2500 - 3500 gram. ${ }^{24}$

Hasil yang berbeda ditemukan pada total pemeriksaan kehamilan atau $A N C$ dan usia ibu saat hamil yang tidak ditemukan berpengaruh terhadap berat bayi lahir. Evans dan Lien menemukan bahwa tidak ada hubungan yang signifikan antara $\mathrm{An}$ tenatal care dengan berat lahir. ${ }^{25}$ Hasil penelitian tersebut berbeda dengan penelitian yang dilakukan oleh Gogoi bahwa Antenatal care yang kurang dari 4 kali berpengaruh terhadap berat lahir bayi yang rendah, selain itu penelitian ini juga menjelaskan bahwa usia ibu berpengaruh signifikan terhadap berat lahir bayi. ${ }^{26}$ Usia ibu kurang dari 18 tahun beresiko 3 kali lebih tinggi untuk melahirkan bayi dengan berat lahir bayi rendah. Berat lahir dipengaruhi oleh banyak faktor, $40 \%$ berat lahir dipengaruhi oleh faktor genetik dan $60 \%$ oleh faktor lingkungan. ${ }^{27}$

Berat lahir merupakan indikator dari kondisi selama di dalam utero dan mungkin menjadi mediator antara pengaruh prenatal dan obesitas pada kehidupan setelahnya. Baik berat lahir yang rendah maupun tinggi berhubungan dengan obesitas di kemudian hari. Berat lahir yang rendah berkaitan dengan teori Barker dimana gizi kurang pada masa awal periode kehidupan dapat berpengaruh terhadap pertumbuhan yang cepat pada masa anak-anak sehingga menyebabkan risiko tinggi terjadinya penyakit hipertensi, kardiovaskular, Diabetes tipe 2 pada masa usia dewasa. ${ }^{28}$

Dalam penelitian ini tidak ditemukan adanya pengaruh signifikan antara berat lahir dengan gizi lebih pada remaja. Hasil dalam penelitian ini berbeda dengan penelitian sebelumnya bahwa berat lahir yang semakin tinggi berhubungan positif dengan tingginya nilai IMT dan secara konsisten berhubungan dengan peningkatan risiko obesitas pada anak dan dewasa. ${ }^{29}$ Obesitas merupakan kondisi multifaktor. Seperti yang dijelaskan sebelumnya bahwa fetal programming sangat berpengaruh terhadap pertumbuhan dan perkembangan anak dikemudian hari. Anak yang lahir dengan berat lahir tinggi (kelebihan makanan selama masa utero dan masa awal kehidupan) berakibat pada keseimbangan gizi dan respon hormon yang dapat menganggu regulasi hormon terkait nafsu makan. ${ }^{30}$

Pemberian ASI khususnya durasi yang panjang ( $>6$ bulan) dan pengenalan susu formula yang tidak terlalu cepat sangat direkomendasikan untuk mencegah peningkatan lemak pada anakanak, remaja, dan dewasa awal. ${ }^{31}$ Anak yang mengkonsumsi ASI langsung dari ibunya dapat melakukan kontrol terhadap kebutuhan kalori. Didorong dari rasa lapar dan kenyang bayi dapat meregulasi secara mandiri jumlah, waktu dan seberapa sering mereka minum dibanding anak yang mengkonsumsi dari botol. Hal ini menjadi awal dimana anak dapat mengatur pola makan sejak dini. Selain itu, anak yang mengonsumsi susu formula dengan kandungan gizi tinggi protein menyebabkan terjadinya peningkatan lipogenesis dan 
perkembangan sel lemak. ${ }^{32}$

Namun dalam penelitian ini, durasi pemberian ASI saja kurang dari 6 bulan tidak berpengaruh signifikan terhadap gizi lebih pada remaja. Hasil yang sama tampak dalam penelitian sebelumnya yang juga tidak menemukan hasil yang signifikan antara pemberian ASI terhadap kegemukan pada anak usia pra sekolah ${ }^{33}$ sedangkan hasil penelitian lain menyebutkan anak yang mengkonsumsi ASI saat bayi menunjukkan risiko obesitas yang lebih rendah pada usia 10 tahun. ${ }^{34}$ Hasil yang tidak signifikan ini dapat dikarenakan adanya pola asuh yang baik terhadap anak. Pola asuh dalam pemberian makan menjadi hal yang penting untuk perkembangan kebiasaan dan pola makan anak. ${ }^{35}$ Dalam beberapa penelitian, hubungan antara menyusui dan status gizi anak pada usia 1 tahun menjadi lemah pada usia 7 tahun atau bahkan menghilang kemudian pada masa anakanak atau dewasa. ${ }^{36-38} \mathrm{Hal}$ tersebut dapat terjadi dikarenakan ada kemungkinan bahwa genetik dan faktor lingkungan lainnya, seperti pola diet, sosio kultural, status ekonomi, dan karakteristik orang tua yang dapat mengurangi atau menghilangkan efek menyusui terhadap IMT pada masa anakanak setelah usia 1 tahun. ${ }^{39}$

Status gizi atau IMT ibu merupakan faktor genetik yang dapat memengaruhi status gizi anak dan dalam studi ini terdapat pengaruh yang signifikan antara IMT ibu dengan gizi lebih pada remaja, ibu yang memiliki status gizi lebih (gemuk atau obesitas) memiliki risiko 1.26 kali lebih tinggi anaknya mengalami gizi lebih. Dalam sebuah studi sistematis menunjukkan bahwa kondisi ayah atau ibu yang gemuk atau obesitas meningkatkan risiko peningkatan lemak pada remaja dan risiko tersebut meningkat ketika kedua orang tua mengalami kegemukan. Risiko anak gemuk 1,8 kali lebih tinggi ketika memiliki ayah yang obesitas dan 2,18 kali yang memiliki ibu yang obesitas. Risiko obesitas pada anak meningkat menjadi 2,49 kali pada ayah yang obesitas dan 3,79 kali jika ibu mengalami obesitas. ${ }^{40}$

Selain status gizi ibu, dalam studi ini pendidikan ayah juga berpengaruh terhadap gizi lebih pada remaja. Ayah dengan pendidikan tinggi menjadi salah satu faktor risiko gizi lebih pada remaja, dimana anak yang memiliki ayah dengan pendidikan tinggi berisiko 1,34 kali lebih tinggi men- derita gizi lebih pada anak remaja. Hasil penelitian sebelumnya menunjukkan terdapat hubungan yang negatif antara pendidikan ayah dengan obesitas remaja, dimana lama pendidikan ayah lebih dari 12 tahun lebih justru risiko remaja menjadi obesitas semakin rendah dibandingkan dengan ayah yang lama pendidikannya kurang dari 6 tahun. ${ }^{41}$ Pendidikan erat kaitannya dengan gradien sosial ekonomi yang kemudian berhubungan dengan pola makan dan aktivitas fisik anak. Sebuah penelitian menyebutkan bahwa anak dengan pendidikan ayah yang tinggi sejalan dengan pendapatan dan waktu kerja ayah yang lebih tinggi, hal ini menyebabkan kurangnya pola asuh yang baik. Kurangnya pola asuh ini berakibat pada kurangnya perhatian terhadap makanan yang dikonsumsi pada anak dan juga kurangnya perhatian terhadap aktivitas fisik anak sehingga anak sering menghabiskan waktu dengan menonton televisi atau bermain game. ${ }^{42}$

Berbeda dengan pendidikan ayah, dalam penelitian ini, pendidikan ibu justru tidak berpengaruh terhadap gizi lebih pada remaja. Hasil studi ini menunjukkan bahwa pendidikan ibu tidak berpengaruh terhadap gizi lebih. Sebuah penelitian lain juga menyatakan bahwa pendidikan ibu berhubungan positif terhadap risiko obesitas hanya pada awal usia remaja (usia 10 tahun) tetapi tidak berhubungan setelah terjadi perubahan usia dari 10 hingga 18 tahun. Hal ini mengindikasikan bahwa pendidikan ibu mungkin berefek hanya sementara terhadap risiko obesitas anak pada awal remaja, namun kontribusinya menjadi semakin lemah seiring dengan adanya faktor lain seperti keadaan keluarga selama masa remaja diantaranya adalah seperti pendidikan ibu, wilayah tinggal, kondisi ekonomi keluarga, jumlah keluarga. ${ }^{43}$ Berbeda dengan peran ayah, ibu memegang peranan penting dalam menyediakan dan menyajikan makanan yang bergizi dalam keluarga, sehingga berpengaruh terhadap status gizi anak. ${ }^{44}$ Pada level individu, pendidikan ibu yang semakin tinggi berkontribusi terhadap perubahan kemampuan, kepercayaan dan pemilihan terhadap kesehatan dan praktik gizi yang kemudian berefek terhadap faktor kesehatan anak dalam hal ini status gizi. Hal yang sama juga ditemukan pada variabel wilayah tinggal, yang tidak ditemukan hubungan signifikan terhadap gizi lebih remaja. Meski tidak menunjuk- 
kan hubungan yang tidak signifikan, hasil dari studi ini menunjukkan bahwa anak yang tinggal di kota cenderung berisiko 1,2 kali mengalami gizi lebih dibanding anak yang tinggal di desa. ${ }^{13}$

Ada banyak bukti kuat yang menghubungkan status sosial ekonomi dengan obesitas pada anak. Anak yang tumbuh dalam keluarga miskin cenderung untuk mengalami gemuk atau obesitas dibanding anak yang tumbuh dalam keluarga kaya. Keluarga yang kaya dapat berdampak baik untuk anak, karena anak mendapat fasilitas yang baik seperti kebersihan dan pelayanan lainnya. Selain itu juga dapat membeli makanan yang berkualitas dan memasukkan anak ke klub olahraga, misalnya. Namun, pendapatan tinggi tidak selalu memperhatikan investasi pada kualitas makan atau pola asuh yang lebih baik. ${ }^{45}$ Peningkatan ketersediaan (availibitas) makanan, khususnya makanan tinggi energi (seperti asupan tinggi produk hewani, dairy, dan makanan tinggi gula) dan rendahnya pengeluaran energi berdampak terhadap obesitas. ${ }^{46}$

\section{KESIMPULAN DAN SARAN}

Faktor yang memengaruhi berat lahir adalah usia kehamilan, dimana usia kehamilan yang semakin tua berisiko melahirkan anak dengan berat lahir semakin tinggi. Berdasarkan faktor langsung yang memengaruhi status gizi lebih pada remaja adalah IMT ibu dan pendidikan ayah. Ibu yang memiliki gizi lebih berpengaruh terhadap gizi lebih pada remaja. Pendidikan ayah yang semakin tinggi menjadi faktor risiko gizi lebih pada remaja. Penelitian lebih lanjut dibutuhkan untuk mengkaji pengaruh asupan makan dan aktivitas fisik, sehingga diketahui besar pengaruh riwayat lahir setelah adjusment dengan kedua variabel tersebut.

\section{DAFTAR PUSTAKA}

1. Inchley, J., Currie, D., Jewell, J., Breda, J., Barnekow, V. Adolescent Obesity and Related behaviours: Trends and Inequalities in the WHO European Region 2002-2014: Observations from the Health Behaviour in Schoolaged Children (HBSC) WHO Collaborative Cross-National Study. WHO Regional Office for Europe. 2018.

1. Kemenkes RI. Hasil Riset Kesehatan Dasar 2013. Jakarta (ID): Badan Penelitian dan Pengembangan Kesehatan; 2013.
2. Ren, J., Wu, J., Ji, M., Rong, F., Li, Y., Gao, E., Ji, H. The Effect of High Birth Weight on Overweight and Obesity in Childhood and Adolescence A Cohort Study in China. Saudi Med J, 2013;34(6):623-631.

3. Husnah. Nutrisi Pada 1000 Hari Pertama Kehidupan. Jurnal Kedokteran Syiah Kuala. 2017;17(3):197-183.

4. Makela J. Genetic, Prenatal and Postnatal Determinants of Weight Gain and Obesity In Young Children - The STEPS Study [Thesis]. Findland: University of Turku; 2015.

5. Devriany, A., Zenderi, W., Yunihar. Perbedaan Status Pemberian ASI Eksklusif terhadap Perubahan Panjang Badan Bayi Neonatus. Jurnal Media Kesehatan Masyarakat Indonesia (MKMI), 2018;14(1):44-51.

6. Von Kries, R., Koletzko, B., Sauerwald, T., von Mutius, E., Barnert, D., Grunert, V., von Vosh, H. Breast Feeding and Obesity: Crosssectional Study. BMJ, 1999; 319(7203):14750.

7. Arenz, S., Rückerl, R., Koletzko, B., von Kries, R. Breast-Feeding and Childhood Obesity a Systematic Review. Int J Obes Relat Metab Disord, 2004; 28:1247-1256.

8. Hales, C.N., Barker, D.J. The Thrifty Phenotype Hypothesis. Br Med Bull, 2001; 60(1):520.

9. Warta Kesmas. Cegah Stunting itu Penting Edisi 02. Jakarta: Kementerian Kesehatan Republik Indonesia; 2018.

10. Patsopoulou, A., Tsimtsiou, Z., Katsioulis, A., Rachiotis, G., Malissiova, E., Hadjichristodoulou, C. Prevalence and Risk Factors of Overweight and Obesity among Adolescents and Their Parents in Central Greece (FETA Project). Int. J. Environ. Res. Public Health, 2016;13. 83.

11. UNICEF. Improving Child Nutrition. The Achievable Imperative for Global Progress. USA; 2013.

12. Miller, J.E., Rodgers, Y.V. Mother's Education and Children's Nutrition Status: New Evidence from Cambodia. Asian Development Review, 2009;26(1): 131-165.

13. Strauss, J., Sikoki, B., Dwiyanto, A., Herawati, Y., Witoelar, F. The Third Wave of the Indonesia Family Life Survey (IFLS3): Overview 
and Field Report; 2004.

14. Strauss, J., Witoelar, F., Sikoki, B., Wattie, A.M. The Fourth Wave of the Indonesia Family Life Survey (IFLS4): Overview and Field Report; 2009.

15. Strauss, J., Witoelar, F., Sikoki, B. The Fifth Wave of the Indonesia Family Life Survey (IFLS5): Overview and Field Report;2016.

16. Kemenkes RI. Pedoman Pencegahan dan Penanggulangan Kegemukan dan Obesitas pada Anak Sekolah. Jakarta: Kementerian Kesehatan RI; 2012.

17. Ballard, O., Morrow, A.L. Human Milk Composition: Nutrients and Bioactive Factors. Pediatr Clin North Am, 2013; 60(1):49-74.

18. Fall, C.H.D., Sachdev, H.S., Osmond, C., Restrepo-Mendez, M.C., Victoria, C., Martorell, R. et al. Association between Maternal Age at Childbirth and Adult Outcomes in the off Sprin: a Prospective Study in Five Low-Income and Middle-Income Countries (COHORT Collaboration). The Lancet, 2015;3(7): 366-377.

19. Sharma, M., Mishra, S. Effects of Maternal Health and Nutrition on Birth Weight of Infant. International Journal of Science and Research, 2014; 3(6):855-858.

20. Han, J.C., Kimm, S.Y.S. Childhood Obesity-2010: Progress and Challenges. Lancet, 2010; 375:1737-1748.

21. Oddy, W.H., Mori, T.A., Huang, R., Marsh, J.A., Pennell, C.E., Chivers, P.T., Hands, B.P., Jacoby, P., Rzehak, P., Koletzko, B.V., Beilin, L.J. Early Infant Feeding and Adiposity Risk: From Infancy to Adulthood. Ann Nutr Metab,2018; 64:262-270.

22. Dubey, M., Rout, A.J., Ram, R., Sha, J.B., Chakraborty, M., Biswas, N. Relationship between Low Birth Weight of Babies and Antenatal Care of Mothers: A Cross Sectional Study at a Tertiary Care Hospital of Kishanganj, Bihar. GJMEDPH. 2014;4(6).

23. Prawirohardjo S. Ilmu Kebidanan. Jakarta: P.T Bina Pustaka Sarwono Prawirohardjo;2012.

24. Evans, W.N., Lien, D.S. The Benefits of Prenatal Care: Evidence from the PAT Bus Strike. Journal of Econometrics, 2005; 125:207-39.

25. Gogoi N. Maternal and Neonatal Risk Factors of Low Birth Weight in Guwahati Metro, As- sam, Northeast India. Acad J Ped Neonatol. 2018; 6(5):555754.

26. Abubakari, A., Kynast-Wolf, G., Jahn, A. Maternal Determinants of Birth Weight in Northern Ghana. PLoS ONE, 2015;10(8): e0135641.

27. Kwon, E.J., Kim, Y.J. What is Fetal Programming?: a Lifetime Health is Under the Control of in Utero Health. Obstetrics \& Gynecology Science. 2017;60(6):506-519.

28. Persons, R.K., Sevdy, T.L., Nichols, W.N. Does Birth Weight Predict Childhood Obesity? Journal of Family Practice. 2008;57:409410.

29. Ren, J., Wu, J., Ji, M., Rong, F., Li, Y., Gao, E., Ji, H. The Effect of High Birth Weight on Overweight and Obesity in Childhood and Adolescence. Saudi Med J, 2013; 34(6): 623-631.

30. Oddy, W.H., Mori, T.A., Huang, R., Marsh, J.A., Pennell, C.E., Chivers, P.T., Hands, B.P., Jacoby, P., Rzehak, P., Koletzko, B.V., Beilin, L.J. Early Infant Feeding and Adiposity Risk: From Infancy to Adulthood. Ann Nutr Metab, 2018;64:262-270.

31. Uwaezuoke, S.N., Eneh, C.I., Ndu, I.K. Relationship between Exklusive Breastfeeding and Lower Risk of Childhood Obesity: A Narrative Review of Published Evidence. Clin Med Insights Pediatr, 2017;11:1-7.

32. Heppe, D.H.M., Jong, J.C.K., Durmuş, B., Moll, H.A., Raat, H., Hofman, A., Jaddoe, V.W.V. Parental, Fetal, and Infant Risk Factors for Preschool Overweight: the Generation R Study. Pediatr Res, 2013;73(1):120-127.

33. Huang, D.Y.C., Lanza, H.I.L., Anglin, M.D. Trajectory of Adolescent Obesity: Exploring the Impact of Prenatal to Childhood Experiences. J Child Fam Stud, 2014; 23(6): 10901101.

34. Danford, C.A., Schultz, C.M., Marvicsin, D. Parental Role in the Development of Obesity in Childre: Challenges and Opportunities. Research and Reports in Biology, 2015;6:39-53.

35. Scholtens, S., Gehring, U., Brunekreef, B., Smit, H.A., de Jongste, J.C., Kerkhof, M. et al. Breastfeeding, Weight Gain in Infancy, and Overweight at Seven Years of Age: the Prevention and Incidence of Asthma and Mite Allergy Birth Cohort Study. Am J Epidemiol, 2007;165:919-26. 
36. O'Tierney, P.F., Barker, D.J., Osmond, C., Kajantie, E., Eriksson, J.G. Duration of Breast-feeding and Adiposity in Adult Life. J Nutr, 2009; 139:422S-5S.

37. Schack-Nielsen, L., Sørensen, Tia., Mortensen, E.L., Michaelsen, K.F. Late Introduction of Complementary Feeding, Rather than Duration of Breastfeeding, May Protect Against Adult Overweight. Am J Clin Nutr, 2010;91:619-27.

38. Vafa, M., Moslehi, N., Afshari, S., Hossini, A., Eshraghian. Relationship between Breastfeeding and Obesity in Childhood. J Health Popul Nutr, 2012; 30(3):303-310.

39. Birblis, M., Mougios, V. Manios Y. Obesity in Adolescence is Associated with Perinatal Risk Factors, Parental BMI and Sociodemographic Characteristics. European Journal of Clinical Nutrition, 2013;67(1):115-121.

40. Ullman, S.H., Buttenhem, A.M., Goldman, N., Pebley, A.R., Wong, R. Socioeconomic Differences in Obesity among Mexican Adolescents. International Journal of Pediatric Obesity, 2011;6:e373-e380.

41. Smetania, N., Albaviciute, E., Babinska,
V., Karinauskiene, L., Wikland, K.A., Petrauskiene, A., Verkauskiene, R. Prevalence of Overweight/Obesity in Relation to Dietary Habits and Lifestyle among 7-17 Years Old Children and Adolescents in Lithuania. BMC Public Health, 2015; 15:1001.

42. Huang, D.Y.C., Lanza, H.I.L., Anglin, M.D. Trajectory of Adolescent Obesity: Exploring the Impact of Prenatal to Childhood Experiences. J Child Fam Stud, 2014;23(6):10901101.

43. Lazzeri, G., Casorell, A., Giallombardo, D., Grasso, A., Guidoni,C., Menoni. E., Giacchi, M. Nutritional Surveillance in Tuscany: Maternal Perception of Nutrional Status of 8-9 Y-Old SchoolChildren. Jurnal of Preventive Medicine And Hygiene, 2006; 47:16-21

44. Gwozdz W. Is Maternal Employment Related to Childhood Obesity? IZA World of Labor; 2016. pp. 267.

45. Popkin, B.M. Global Changes in Diet and Activity Patterns as Drivers of the Nutrition Transition. Nestle. Nutr. Workshop Ser. Pediatr. Program, 2009; 63:1-10. 